\title{
Application of silicon nanoparticles in agriculture
}

\author{
Anshu Rastogi ${ }^{1}$ (D) Durgesh Kumar Tripathi ${ }^{2} \cdot$ Saurabh Yadav $^{3} \cdot$ Devendra Kumar Chauhan $^{4} \cdot$ Marek Živčák $^{5}$. \\ Mansour Ghorbanpour ${ }^{6} \cdot$ Nabil Ibrahim El-Sheery ${ }^{7} \cdot$ Marian Brestic $^{5}$
}

Received: 8 November 2018 / Accepted: 8 February 2019 / Published online: 18 February 2019

(c) The Author(s) 2019

\begin{abstract}
The beneficial effects of silicon and its role for plants are well established; however, the advantages of silicon nanoparticles over its bulk material are an area that is less explored. Silicon nanoparticles have distinctive physiological characteristics that allow them to enter plants and influence plant metabolic activities. The mesoporous nature of silicon nanoparticles also makes them good candidates as suitable nanocarriers for different molecules that may help in agriculture. Several studies have shown the importance of silicon nanoparticles in agriculture, but an overview of the related aspects was missing. Therefore, this review brings together the literature on silicon nanoparticles and discusses the impact of silicon nanoparticles on several aspects of agricultural sciences. The review also discusses the future application of silicon nanoparticles in plant growth, plant development, and improvement of plant productivity.
\end{abstract}

Keywords Silicon $\cdot$ Mesoporous $\cdot$ Nanocarrier $\cdot$ Fertilizers

\section{Introduction}

A metalloid is an element with intermediate physical and chemical properties between those of metals and nonmetals. Among the different metalloids, silicon is the most common on earth and is the second most abundant element in

Anshu Rastogi and Durgesh Kumar Tripathi have contributed equally to the work.

Anshu Rastogi

anshu.rastogi@up.poznan.pl

1 Meteorology Department, Poznan University of Life Sciences, Piątkowska 94, Poznań 60-649, Poland

2 Amity Institute of Organic Agriculture (AIOA) Amity University, Noida 201313, India

3 Department of Biotechnology, Hemvati Nandan Bahuguna Garhwal (Central) University, Srinagar Garhwal, Uttarakhand 246174, India

4 D D Pant Interdisciplinary Research Laboratory, Department of Botany, University of Allahabad, Allahabad, India

5 Department of Plant Physiology, Slovak University of Agriculture, A. Hlinku 2, Nitra 94976, Slovakia

6 Department of Medicinal Plants, Faculty of Agriculture and Natural Resources, Arak University, Arak, Iran

7 Agricultural Botany Department, Faculty of Agriculture, Tanta University, Tanta, Egypt the earth's crust after oxygen (Epstein 1994). Silicon is also considered somewhere between an essential and nonessential element for plants, as it is not required for the survival of most plants, but plants benefit and are better adapted to different environmental stress conditions in the presence of silicon (Epstein 1994; Luyckx et al. 2017). Silicon has also been observed to be used by plants to strengthen their cell walls; the plants of the Equisetaceae family cannot survive in nutrient solutions lacking silicon (Epstein 1994). Therefore, silicon is considered an essential element for the Equisetaceae family (Epstein 1994). Silicon content in plants was observed to vary from 0.1 to $10 \%$, which was attributed to different mechanisms of silicon uptake (Liang et al. 2007). Dissolved silicon was reported to be absorbed by plants in the form of monosilicic acid, and in some plants with a high accumulation capacity of metalloids, different silicon transporter genes (such as LSi1, LSi2, and LSi6) have been reported to help in its transportation (Rao and Susmitha 2017). Nanoparticles may exhibit different properties than their bulk material due to their small size, greater surface area-to-weight ratio, and different shapes (Roduner 2006). Similarly, silicon nanoparticles (Si-NPs) were observed to exhibit different physical and chemical properties than their bulk material (O'Farrell et al. 2006). Therefore, it is important to know how differently Si-NPs interact within the environment. Due to their unique properties, Si-NPs exhibit 
great potential in agriculture and may work better in alleviating different abiotic stresses than bulk material (Tripathi et al. 2015, 2017; Cui et al. 2017; Abdel-Haliem et al. 2017). Apart from the direct impact of Si-NPs on plant growth and development, Si-NPs can also be used as nanopesticides, nanoherbicides, and nanofertilizers (Fig. 1). Silicon nanoparticles may also be used as delivery agents for proteins, nucleotides, and other chemicals in plants; nanozeolite and nanosensors incorporate Si-NPs and may be effectively used in agriculture for increasing the water retention of soil and for soil monitoring, respectively (Fig. 1). The focus of this review is to systematically present the potential of Si-NPs in agriculture.

In the following sections, we will discuss the direct and indirect impact of Si-NPs on plants and discuss their importance in agriculture.

\section{Direct impact of Si-NPs on plants}

The response of plants to nanoparticles depends on various factors, including the size, shape, method of application, chemical properties, and physical properties of the nanoparticles (Rastogi et al. 2017). Recent studies have shown that Si-NPs may directly interact with plants and impact their morphology and physiology in various ways, including the addition of structural color to the plants, and help in improving plant growth and yield (Bao-shan et al. 2004; Strout et al. 2013; Suriyaprabha 2014; Siddiqui and Al-Whaibi 2014). Some studies have also indicated a negative impact of SiNPs on plants (Slomberg and Schoenfisch 2012; Le et al. 2014). To provide a better understanding, important studies involving plants and Si-NPs are summarized in Table 1.

Silicon nanoparticles were observed to form a binary film at the epidermal cell wall after absorption, which may add structural color to plants (Strout et al. 2013). The impact was not limited to coloring; Si-NPs were also speculated to act as a strengthening material that may act as an agent to prevent fungal, bacterial, and nematodal infections and, thus, may increase disease resistance. The authors also concluded that a nano-silicon layer may reduce plant transpiration and, thus, make plants more resistant to drought, high temperature, and humidity.

In most studies, Si-NPs were observed to be beneficial to or ineffective for plants by either supporting plant growth or having no impact (Bao-shan et al. 2004; Suriyaprabha 2014; Siddiqui and Al-Whaibi 2014), except for a few reports where Si-NPs were observed to have a negative impact on plants (Slomberg and Schoenfisch 2012; Le et al. 2014). Slomberg and Schoenfisch (2012) reported that the toxic impact of Si-NPs was due to the change in $\mathrm{pH}$ in growth media that occurred due to the addition of Si-NPs.
Fig. 1 Si-NP in agriculture: The illustration presents the potential use of Si-NP in agriculture

\section{Growth Regulator}
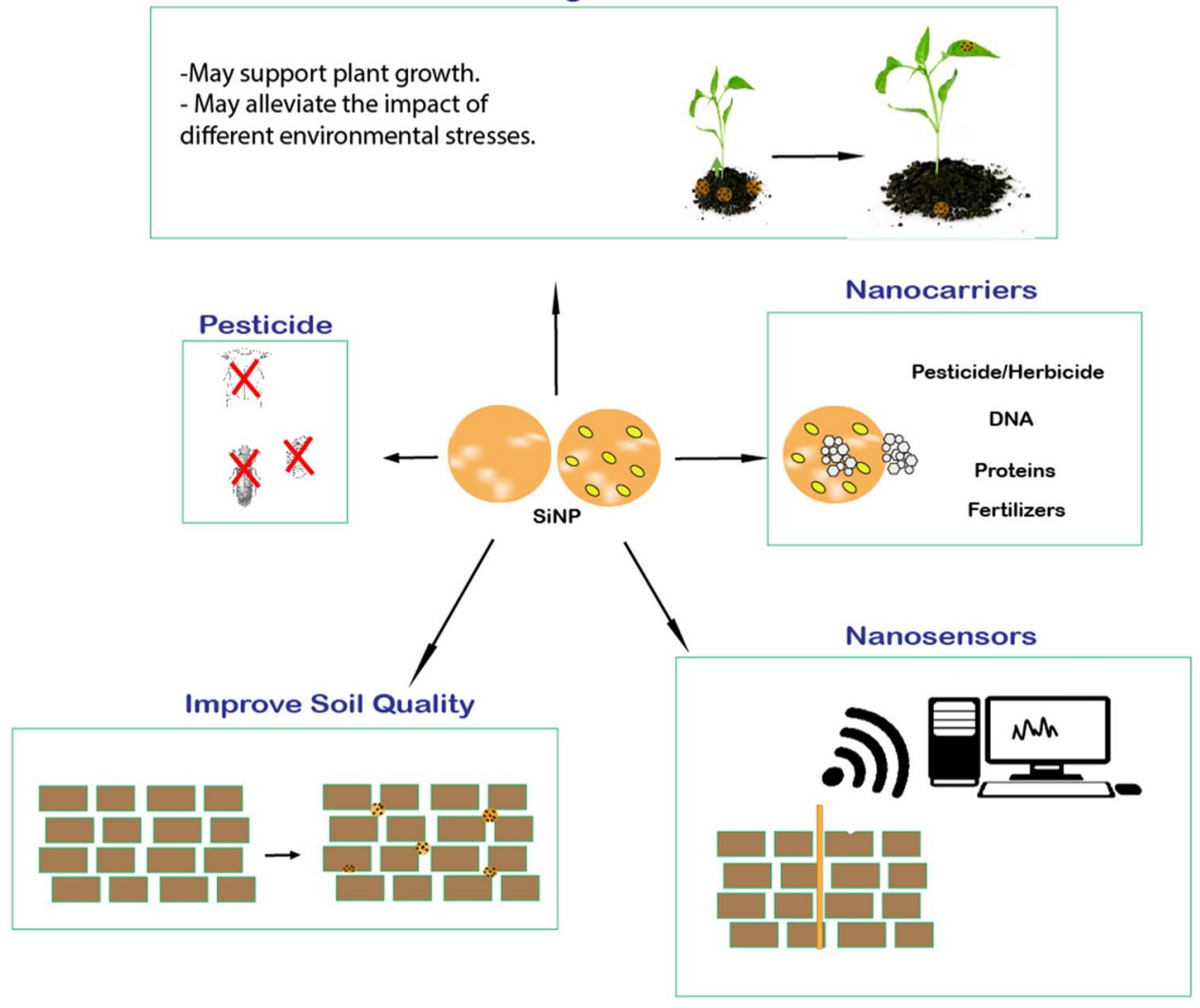


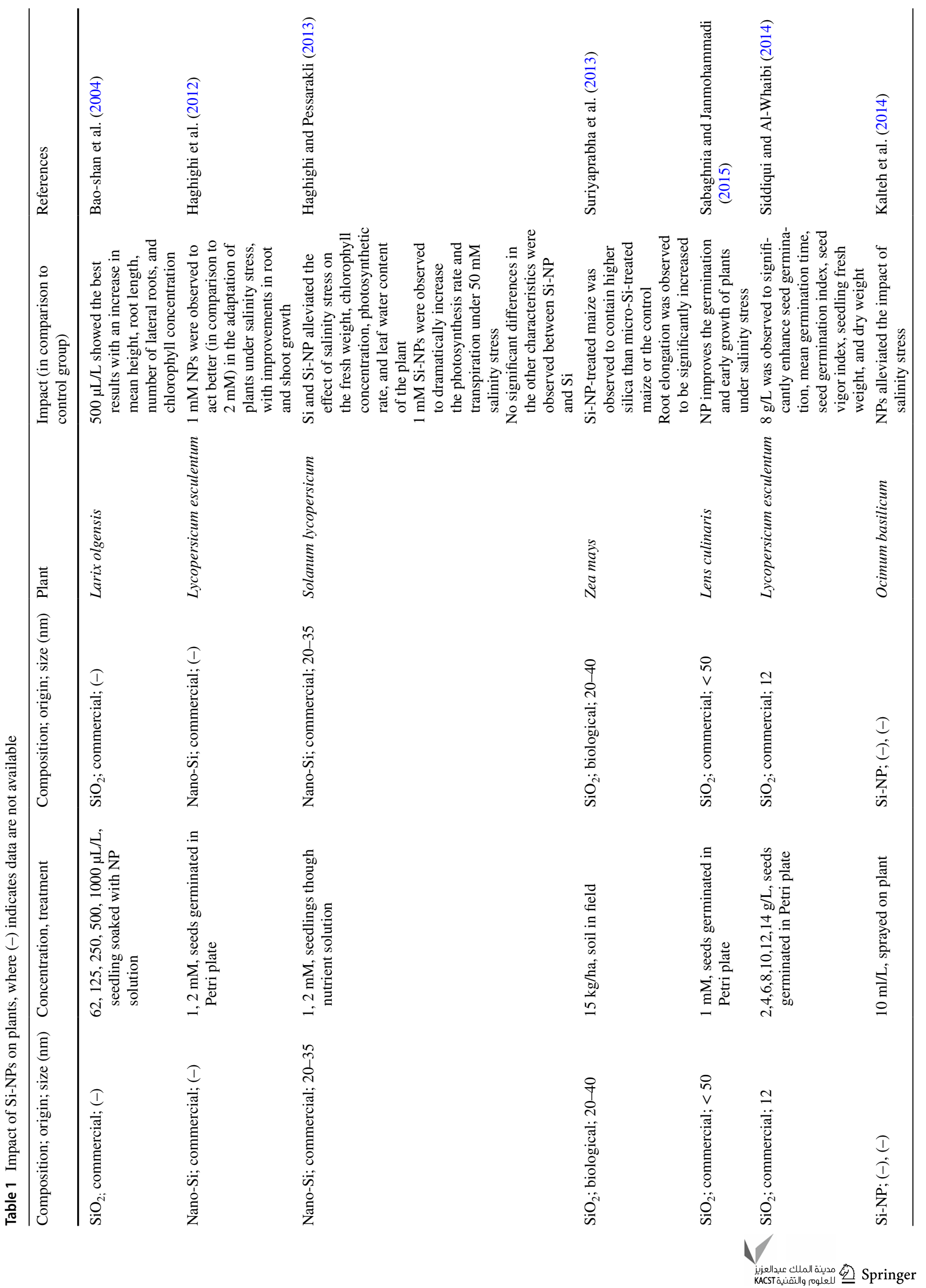




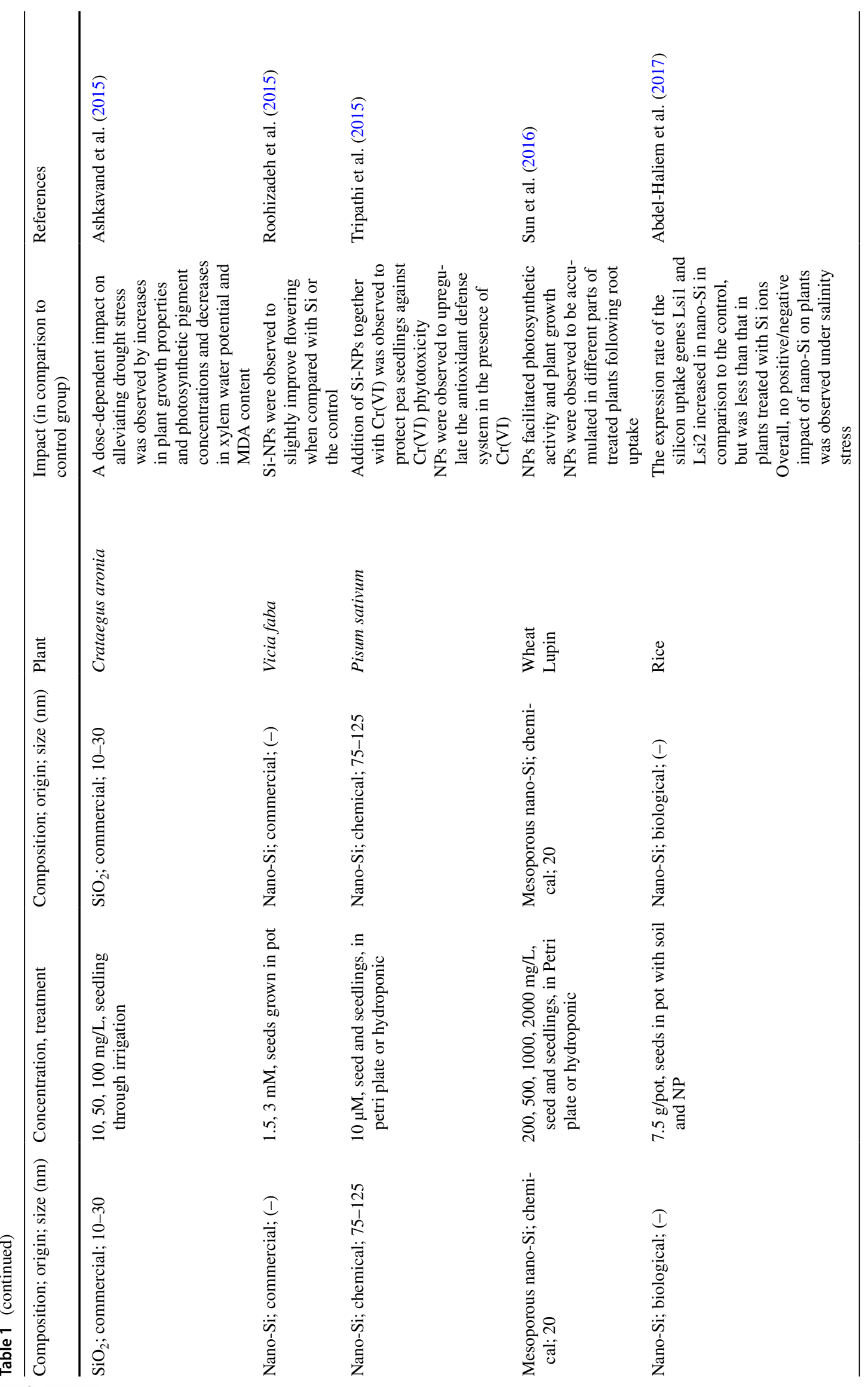




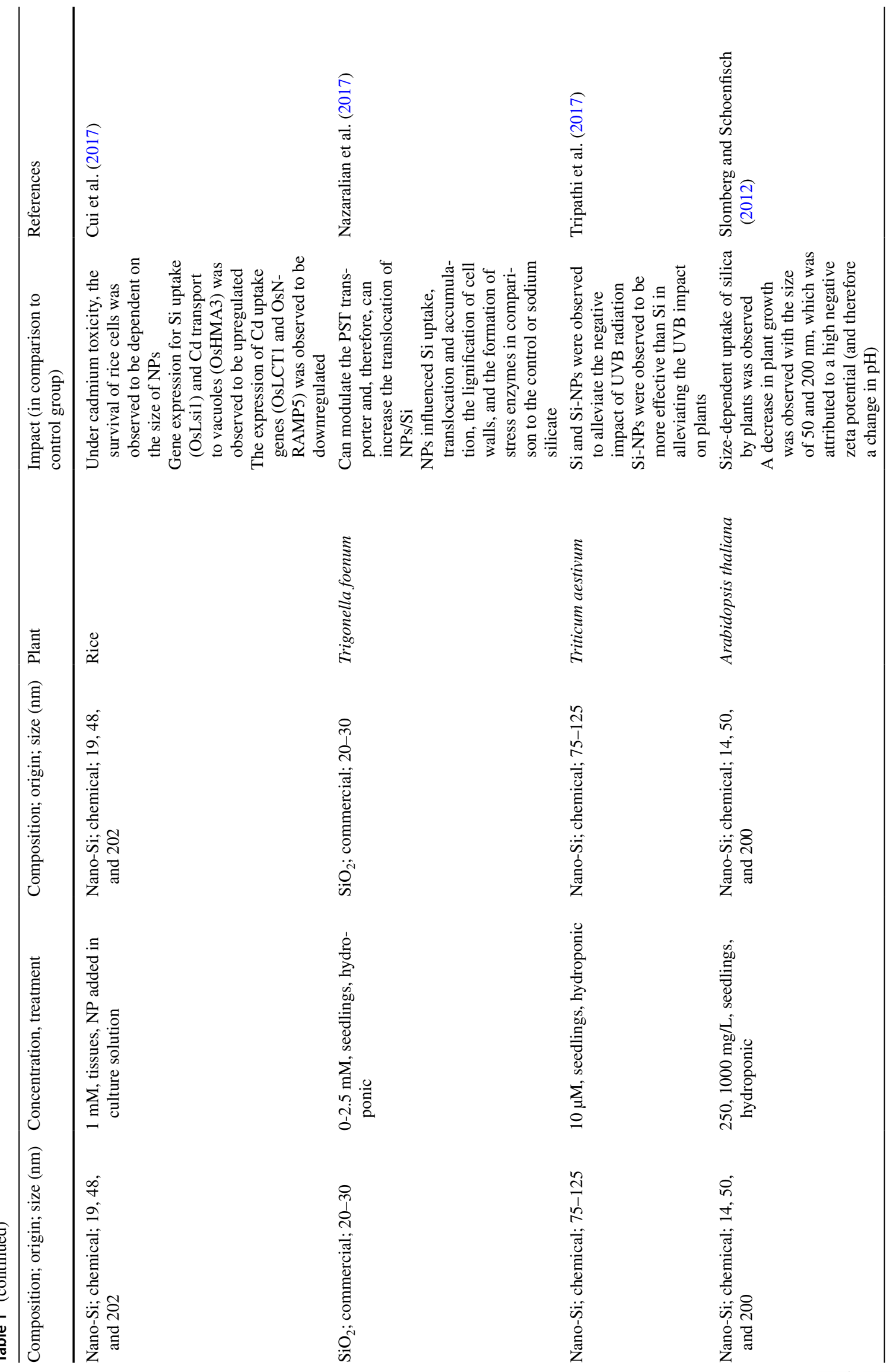


The author observed that, after excluding the change in $\mathrm{pH}$, Si-NPs were ineffective for Arabidopsis. A study by Le et al. (2014) did not study zeta potential or pH maintenance, because the authors lacked information about the properties of Si-NPs, which raises questions about the phytotoxicity of Si-NPs.

\section{Use of Si-NPs in agriculture}

The unique physiochemical properties of nanoscale silicon particles have useful applications in different sectors, including promising applications in the agricultural sector. The unique properties of Si-NPs allow them to cope with agricultural damage that may occur through climate change and/or abiotic stress (Tripathi et al. 2012). The application of Si-NPs in agriculture may also lead to global food security by helping in the development of improved varieties with high productivity (Parisi et al. 2015). Silicon nanoparticles are promising and have agricultural implications, and several new applications are being investigated for plants. In the agricultural sector, Si-NPs were observed to be applied as a weapon against heavy metal toxicity (Cui et al. 2017), UVB stress (Tripathi et al. 2017), salinity stress (AbdelHaliem et al. 2017), dehydration (Jullok et al. 2016), etc. Moreover, additional novel applications of Si-NPs include their use as fertilizers, pesticides, and herbicides. Therefore, Si-NPs have the potential to improve crops for sustainable agriculture.

\section{Si-NPs as pesticides}

In the present decade, nanotechnology has intervened in helping develop disease-free agricultural crops (Gogos et al. 2012). Under the large umbrella of nanotechnology, nanosilica, a unique type of nanomaterial, is used as a nanopesticide. A number of studies point towards the use of Si-NPs as nanopesticides (Ulrichs et al. 2005; Rouhani et al. 2012; El-Bendary and El-Helaly 2013; Magda and Hussein 2016; Ziaee and Ganji 2016). Si-NPs have been observed to be used in two ways: either Si-NPs were directly applied in the field and played the role of pesticides, killing insects and larvae, or mesoporous silica nanoparticles were used as nanocarriers that released commercial pesticides to enhance their efficiency. It was shown that $\mathrm{SiO}_{2}$ NPs had lethal properties for Callosobruchus maculatus (Rouhani et al. 2012); it was observed that the nanoparticles were more effective on adult insects than larvae, and it was speculated that the impact could be due to dehydrating properties of silica, which may result in impairment of the digestive tract or surface enlargement of the integument. The lethal impact of Si-NPs for 
pests can also be due to blockage of spiracles and tracheas or damage to the protective wax coating on the cuticle by sorption and abrasion. Some related and similar impacts of Si-NPs on different insects are listed in Table 2. A surface-charged modified hydrophobic nanosilica ( $\sim 3$ to $5 \mathrm{~nm}$ ) demonstrated the potential to eradicate an array of crop insects, pests, and animal ectoparasites of veterinary importance (Ulrichs et al. 2005). The working mechanism by which nanosilica controls pests was speculated to be breaking the protective lipid water barrier by physisorption of nanosilica, which resulted in the death of targeted organisms (Ulrichs et al. 2005; Rai and Ingle 2012). To improve the efficacy of pesticides, it is imperative to release the pesticide at the targeted site. However, for the controlled release of bioformulations, mesoporous silica nanoparticles are essential to deliver pesticides ( $\mathrm{Li}$ et al. 2007; Chen et al. 2011). Several reports have shown that mesoporous nanosilica increased the durability of commercial pesticides and their efficiency (Table 2). The studies clearly indicated that the Si-NPs are effective pesticides and can be used either alone or to facilitate the delivery of the other commercial pesticides.

\section{Si-NPs as a delivering agent for herbicides and fertilizers}

Due to the unique physical and chemical properties of silicon nanoparticles, they can easily enter into plant cells and affect the plant growth and development by affecting their metabolism through diverse interactions, thereby triggering the potential to combat stress conditions. In the present scenario, where the focus is to increase crop productivity or to eradicate weeds, Si-NPs may act as an agent for target-specific delivery of herbicides and fertilizers (Wanyika et al. 2012). Silicon nanocarriers have been observed to carry herbicides (chloroacetanilide, anilide, and benzimidazole) embedded in a diatom fistule and deliver the herbicide to the field in its active form (Lodriche et al. 2012). In the case of fertilizer delivery, studies signified that the application of nano-silicon dioxide with organic fertilizer was used to improve plant productivity (Janmohammadi et al. 2016). Mesoporous silica nanoparticles (MSNs) with a specific pore size $(2-10 \mathrm{~nm})$ served as an efficient delivery vector for urea-, boron-, and nitrogenous-based fertilizers (Torney et al. 2007; Wanyika et al. 2012) (Table 3). Thus, Si-NPs have the potential to be used as a fertilizer alone for specific crops and can be used to deliver herbicides and fertilizers in plants.

Table 2 The role of Si-NPs as pesticides

\begin{tabular}{|c|c|c|c|c|}
\hline Composition; Size (nm) & $\begin{array}{l}\text { Concentration; species effective } \\
\text { against }\end{array}$ & Impact & \multicolumn{2}{|c|}{ References } \\
\hline $\mathrm{SiO}_{2} ; 20-60$ & $\begin{array}{l}1,1.5,2 \text {, and } 2.5 \mathrm{~g} / \mathrm{kg} ; \text { Callosobru- } \\
\text { chus maculatus }\end{array}$ & $\begin{array}{l}\text { Kills insect and larvae in a dose- } \\
\text { dependent manner } \\
\text { Useful in protection of stored grain }\end{array}$ & \multicolumn{2}{|c|}{ Rouhani et al. (2012) } \\
\hline Si-NPs; (-) & $\begin{array}{l}\text { 200, } 300,400, \text { and } 500 \mathrm{ppm} ; \text { Spodop- } \\
\text { tera littoralis }\end{array}$ & $\begin{array}{l}\text { Kills larvae in a dose-dependent } \\
\text { manner } \\
\text { Increases plant longevity and number } \\
\text { of leaves per plant after } 15 \text { days of } \\
\text { application }\end{array}$ & \multicolumn{2}{|c|}{ El-Helaly et al. (2016) } \\
\hline $\mathrm{SiO}_{2} ; 12,20-30$ & $\begin{array}{l}\text { 50, } 100,200, \text { and } 300 \mathrm{ppm} ; \text { Rhyzoper- } \\
\text { tha dominica, Tribolium confusum }\end{array}$ & $\begin{array}{l}\text { Kills insects in a dose- and size- } \\
\text { dependent manner } \\
\text { The impact of NPs was observed to be } \\
\text { more intensive on wheat grains than } \\
\text { barley grains } \\
\text { Useful in protection of stored grains }\end{array}$ & \multicolumn{2}{|c|}{ Ziaee and Ganji (2016) } \\
\hline Composition & Encapsulated pesticide & Benefits & & References \\
\hline $\begin{array}{l}\text { Si-NPs; thickness } \sim 15 \mathrm{~nm} \text {, surface } \\
\text { area } \sim 588 \mathrm{~m}^{2} \mathrm{~g}^{-1} \text {, pore diameter } \\
4-5 \mathrm{~nm}\end{array}$ & Avermectin & $\begin{array}{l}\text { Increased photostability of pestici } \\
\text { sustained release. }\end{array}$ & de and & Li et al. (2007) \\
\hline $\begin{array}{l}\text { Si-NPs; surface area } 822 \mathrm{~m}^{2} \mathrm{~g}^{-1} \text {, pore } \\
\text { diameter } 2.4 \mathrm{~nm}\end{array}$ & Pyoluteorin & $\begin{array}{l}\text { Sustained release }(85.13 \% \text { within } \\
\text { days) } \\
\text { Increased antifungal activity } \\
\text { Pesticide degrades in alkaline con } \\
\text { but when encapsulated in Si-NP } \\
\text { not degraded. }\end{array}$ & $\begin{array}{l}28 \\
\text { ditions, } \\
\text { s, it is }\end{array}$ & $\begin{array}{l}\text { Chen et al. } \\
\text { (2011) }\end{array}$ \\
\hline
\end{tabular}


Table 3 Si-NP as fertilizers

\begin{tabular}{|c|c|c|c|}
\hline Composition & Herbicide/fertilizer & Benefits & References \\
\hline $\begin{array}{l}\mathrm{SiO}_{2} \mathrm{NP} \text {, Size } 20-30 \mathrm{~nm}, 180- \\
600 \mathrm{~m}^{2} \mathrm{~g}^{-1}\end{array}$ & $\begin{array}{l}\text { Farmyard manure (FYM), and NPK } \\
\text { fertilizers (applied with } 20 \mathrm{mM} \\
\mathrm{SiO}_{2} \mathrm{NP} \text { ) }\end{array}$ & $\begin{array}{l}\text { The fertilizers were observed to be } \\
\text { significantly effective to improve } \\
\text { growth traits in presence of NP }\end{array}$ & Janmohammadi et al. (2016) \\
\hline $\begin{array}{l}\text { Si-NP; surface area }\left(\sim 1000 \mathrm{~m}^{2} \mathrm{~g}^{-1}\right) \\
\text { pore size }(25 \mathrm{~nm})\end{array}$ & Urease (encapsulated) & $\begin{array}{l}\text { Adsorption of urease increased } \\
\text { Enhancement in stability of urease } \\
\text { was observed after adsorption } \\
\text { May act as useful model for nitrogen } \\
\text { release in soil }\end{array}$ & Hossain et al. (2008) \\
\hline $\begin{array}{l}\text { Si-NP; surface area }\left(1013 \mathrm{~m}^{2} \mathrm{~g}^{-1}\right) \text {; } \\
\text { pore size }(2.5 \mathrm{~nm})\end{array}$ & Urease (encapsulated) & $\begin{array}{l}\text { A burst release of entrapped urea } \\
\text { was observed within } 24 \mathrm{~h} \text {; how- } \\
\text { ever, slow release was observed in } \\
\text { subsequent period } \\
\text { Release profile was slower in soil } \\
\text { than in the water }\end{array}$ & Wanyika et al. (2012) \\
\hline
\end{tabular}

\section{Si-NPs in target-specific delivery of proteins, nucleotides, and chemicals in plants}

The implementation of several nanoplatforms in various fields under in vitro conditions has spawned concerns in agri-nanotechnology. This technology embraces the promise of controlled and regulated release of agrochemicals and site-targeted delivery of various macromolecules, such as proteins, nucleotides, and chemicals, for improved plant resistance and nutrient efficiency, as well as increased crop yields (Nair et al. 2010). Nanoencapsulation has demonstrated the efficient and protected use of chemicals with less release to the environment and ensures eco-protection (Tsuji 2001; Boehm et al. 2003). The uptake, competence, and impact of various nanoparticles on plant growth, development, and biochemical process vary diversely among various plant species. Specifically, the use of MSNs in targeted delivery of various chemicals provides new insight into the safe use of this novel technology for improving crop variety and yield. Mesoporous silicon nanoparticles have chemically and thermally stable structures with large surface areas, tunable pore sizes, and several well-characterized surface properties, which makes them suitable for hosting guest molecules (Torney et al. 2007). In addition, the sizeadjustable 3D open pore structure allows the regulation of adsorption rates to create effective delivery carriers (PérezDe-Luque and Rubiales 2009). Surface-coated MSNs were useful for DNA and SiRNA delivery due to their binding affinity and high cellular uptake (Xia et al. 2009). Likewise, Torney et al. (2007) demonstrated the transportation of DNA and chemicals (with the gene and its chemical inducer) into isolated plant cells and intact leaves through MSNs. The direct delivery of a Cre recombinase protein through goldplated MSNs was also successfully achieved by a biolistic method in maize (Martin-Ortigosa et al. 2014). Therefore, MSNPs have become established as transportation materials and have the potential to be used for the development of genetically modified crops.

\section{Si-NPs as a component of nanozeolite for the purpose of increasing water holding capacity}

Soil is the most essential factor that regulates plant growth by controlling nutrient and water reserves (Ghaemi et al. 2014); therefore, improved soil quality is vital for increasing crop productivity (Lal 2015). Natural zeolites are an important alternative to overcome the effects of drought in arid regions (Ghanbari and Ariafar 2013). Considering the increasing interest in this area, various nanosized zeolites have been prepared and used to improve soil quality, as well as the impacts of chemical and organic fertilizers, for crop improvement (Najafi-Ghiri 2014). To combat negative hydric impacts in soil, nanozeolites act as a slow-release source for water and, therefore, increase the water holding capacity of the soil (Sekhon 2014). Mirzaei et al. (2015) reported the effect of the application of nanozeolite and zeolite on the water-stable mean weight diameter (MWDw), which is an index of aggregation, stability and strength as well as the aggregate size fraction of carbon. The aggregation process plays a substantial role in improving soil physical characteristics, such as water conduction, infiltration, and ventilation. These zeolites and nanozeolites facilitate water infiltration and retention in the soil due to their porous and capillary properties. Zeolites are known to act as natural wetting agents and work as water distributors throughout the soil, ultimately affecting water conduction in plants (Szerment et al. 2014; Ghazavi 2015). Thus, the observed results clearly showed the ability of Si-NPs to enhance the water holding capacity and, therefore, improve soil quality. 


\section{Si-NPs as nanosensors}

In recent decades, environmental sensing technologies based on metallic nanoparticles have gained enormous attention due to their extraordinary sensing resolution and sensitivity to analytes under optical detection. Developing a nanoparticle-based sensing device has been proposed due to the surface area of nanoparticles and the availability of surface anchored bioactive molecules for analyte detection (Hache et al. 1986). Although functionalized nanoparticles such as silver, gold, and $\mathrm{Eu}_{2} \mathrm{O}_{3}$ have been broadly engaged to increase sensory power due to their surfaceenhanced plasmon resonance, with these nanoparticles, there is a risk of altering the surface plasmon resonance spectrum (Jin et al. 2001; Jean et al. 2010). Silica nanoparticles were successfully used as nanosensors for the detection of various metals in soil. The core-shell structure of silica nanoparticles provides immense advantages over the other nanoparticles in terms of sensor stability, accuracy, and sensitivity (Sun et al. 2016). When combined with the other nanoparticles, silicon has the potential to improve stability and sensitivity; by firmly attaching well-separated silver nanoparticles on the silica surface, optical stability and sensitivity in suspensions are improved, and the thinfilm structural configuration acts as a colloidal stabilizer and a spacer for the spatial stabilization of silver nanoparticles (Jean et al. 2010). Si-NPs with silver nanospheres $\left(\mathrm{SiO}_{2} @ \mathrm{Ag}\right)$ were successfully employed as an optical sensor for melamine detection. Similarly, Liu et al. (2014) prepared rhodamine B-doped silica nanoparticles coated with carbon dots and used them as nanosensors for the ratiometric fluorescence imaging of copper ions from tap water. 8-Aminoquinoline-functionalized silica nanoparticles have been shown to be used as fluorescent nanosensors for the analysis of divalent zinc ions in aqueous and yeast cell suspensions (Rastogi et al. 2011). Therefore, the discussed studies clearly indicate that Si-NPs alone or in combination with the other nanoparticles act as effective sensors with potential for agricultural use.

\section{Conclusion and future perspectives}

Nanotechnology is a promising area of interdisciplinary research that opens avenues in several fields, such as medicine, pharmaceuticals, electronics, and agriculture. This article presents the potential of Si-NPs in agriculture and brings together the literature relevant to the use of nanoparticles as pesticides, fertilizers, herbicides, genetic and drug transfer agents, soil improving agents, and sensors for soil analysis. Studies show that Si-NPs have the potential to revolutionize the existing technology used in various sectors, such as agriculture and plant biotechnology. Silicon nanoparticle-mediated targeting of biomolecules would be useful for developing new cultivars that are resistant to various biotic and abiotic factors. These nanoparticles can provide green and eco-friendly alternatives to various chemical fertilizers without harming nature. Thus, Si-NPs may have concrete solutions to many agricultural problems regarding weeds, pathogenicity, drought, crop yield, and productivity.

Acknowledgements This work was supported by the research project of the Slovak Research and Development Agency under the project APVV-15-0721, VEGA 1/0923/16, and National Science Centre Poland, under the project UMO-2016/21/B/ST10/02271.

\section{Compliance with ethical standards}

Conflict of interest On behalf of all authors, the corresponding author states that there is no conflict of interest.

Open Access This article is distributed under the terms of the Creative Commons Attribution 4.0 International License (http://creativeco mmons.org/licenses/by/4.0/), which permits unrestricted use, distribution, and reproduction in any medium, provided you give appropriate credit to the original author(s) and the source, provide a link to the Creative Commons license, and indicate if changes were made.

\section{References}

Abdel-Haliem MEF, Hegazy HS, Hassan NS, Naguib DM (2017) Effect of silica ions and nano silica on rice plants under salinity stress. Ecol Eng 99:282-289

Ashkavand P, Tabari M, Zarafshar M, Tomášková I, Struve D (2015) Effect of $\mathrm{SiO}_{2}$ nanoparticles on drought resistance in hawthorn seedlings. For Res Pap 76(4):350-359

Bao-shan L, Chun-hui L, Li-jun F, Shu-chun Q, Min Y (2004) Effect of TMS (nanostructured silicon dioxide) on growth of Changbai larch seedlings. J For Res 15:138-140

Boehm AL, Martinon I, Zerrouk R, Rump E, Fessi H (2003) Nanoprecipitation technique for the encapsulation of agrochemical active ingredients. J Microencapsul 20:433-441

Chen J, Wang W, Xu Y, Zhang X (2011) Slow-release formulation of a new biological pesticide, pyoluteorin, with mesoporous silica. $\mathrm{J}$ Agric Food Chem 59(1):307-311

Cui J, Liu T, Li F, Yi J, Liu C, Yu H (2017) Silica nanoparticles alleviate cadmium toxicity in rice cells: mechanisms and size effects. Environ Pollut 228:363-369

El-Bendary HM, El-Helaly AA (2013) First record nanotechnology in agricultural: silica nano-particles a potential new insecticide for pest control. App Sci Rep 4(3):241-246

El-Helaly AA, El-Bendary HM, Abdel-Wahab AS, El-Sheikh MAK, Elnagar S (2016) The silica-nano particles treatment of squash foliage and survival and development of Spodoptera littoralis (Bosid.) larvae. J Entomol Zool Stud 4(1):175-180

Epstein E (1994) The anomaly of silicon in plant biology. Proc Natl Acad Sci USA 91(1):11-17

Ghaemi M, Astaraei AR, Emami H, Mahalati MN (2014) Determining soil indicators for soil sustainability assessment using principal

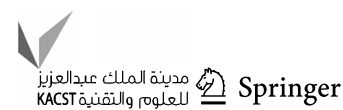


component analysis of Astan Quds- east of Mashhad-Iran. J Soil Sci Plant Nutr 14:987-1004

Ghanbari M, Ariafar S (2013) The effect of water deficit and zeolite application on Growth Traits and Oil Yield of Medicinal Peppermint (Mentha piperita L.). Int J Med Arom Plants 3(1):33-39

Ghazavi R (2015) The application effects of natural zeolite on soil runoff, soil drainage and some chemical soil properties in arid land área. Int J Innov Appl Stud 13(1):172-177

Gogos A, Knauer K, Bucheli TD (2012) Nanomaterials in plant protection and fertilization: current state, foreseen applications, and research priorities. J Agric Food Chem 60(39):9781-9792

Hache F, Ricard D, Flytzanis C (1986) Optical nonlinearities of small metal particles: surface-mediated resonance and quantum size effects. JOSA B 3(12):1647-1655

Haghighi M, Pessarakli M (2013) Influence of silicon and nanosilicon on salinity tolerance of cherry tomatoes (Solanum lycopersicum L.) at early growth stage. Sci Horticult 161C:111-117

Haghighi M, Afifipour Z, Mozafarian M (2012) The effect of N-Si on tomato seed germination under salinity levels. J Biol Environ Sci 6(16):87-90

Hossain KZ, Monreal CM, Sayari A (2008) Adsorption of urease on PE-MCM-41 and its catalytic effect on hydrolysis of urea. Colloids Surf B Biointerfaces 62(1):42-50

Janmohammadi M, Amanzadeh T, Sabaghnia N, Ion V (2016) Effect of nano-silicon foliar application on safflower growth under organic and inorganic fertilizer regimes. Bot Lithuan 22(1):53-64

Jean RD, Chiu KC, Chen TH, Chen CH, Liu DM (2010) Functionalized silica nanoparticles by nanometallic Ag decoration for optical sensing of organic molecule. J Phys Chem C 114(37):15633-15639

Jin R, Cao Y, Mirkin CA, Kelly KL, Schatz GC, Zheng JG (2001) Photoinduced conversion of silver nanospheres to nanoprisms. Science 294(5548): 1901-1903

Jullok N, Van Hooghten R, Luis P, Volodin A, Van Haesendonck C, Vermant J, Van der Bruggen B (2016) Effect of silica nanoparticles in mixed matrix membranes for pervaporation dehydration of acetic acid aqueous solution: Plant-inspired dewatering systems. J Clean Prod 112:4879-4889

Kalteh M, Alipour ZT, Ashraf S, Aliabadi MM (2014) Nosratabadi AF. Effect of silica nanoparticles on basil (Ocimum basilicum) under salinity stress. J Chem Health Risks 4:49-55

Lal R (2015) Restoring soil quality to mitigate soil degradation. Sustainability 7:5875-5895

Le VN, Rui Y, Gui X, Li X, Liu S, Han Y (2014) Uptake, transport, distribution and Bio-effects of $\mathrm{SiO}_{2}$ nanoparticles in Bt-transgenic cotton. J Nanobiotechnol 12:50

Li ZZ, Chen JF, Liu F, Liu AQ, Wang Q, Sun HY, Wen LX (2007) Study of UV-shielding properties of novel porous hollow silica nanoparticle carriers for avermectin. Pest Manag Sci 63(3):241-246

Liang Y, Sun W, Zhu Y-G, Christie P (2007) Mechanisms of siliconmediated alleviation of abiotic stresses in higher plants: a review. Environ Pollut 147(2):422-428

Liu X, Zhang N, Bing T, Shangguan D (2014) Carbon dots based dual-emission silica nanoparticles as a ratiometric nanosensor for $\mathrm{Cu}^{2+}$. Anal Chem 86(5):2289-2296

Lodriche SS, Soltani S, Mirzazadeh R (2012) U.S. Patent Application No. 13/406,538

Luyckx M, Hausman JF, Lutts S, Guerriero G (2017) Silicon and plants: current knowledge and technological perspectives. Front Plant Sci 8:411

Magda S, Hussein MM (2016) Determinations of the effect of using silica gel and nano-silica gel against Tutaabsoluta (Lepidoptera: Gelechiidae) in tomato fields. J Chem Pharm Res 8(4):506-512
Martin-Ortigosa S, Peterson DJ, Valenstein JS, Lin VSY, Trewyn BG, Lyznik LA, Wang K (2014) Mesoporous silica nanoparticlemediated intracellular Cre protein delivery for maize genome editing via loxP site excision. Plant Physiol 164(2):537-547

Mirzaei M, Akbar A, Mohsen S (2015) Aggregation stability and organic carbon fraction in a soil amended with some plant residues, nanozeolite, and natural zeolite. Int J Recycl Org Waste Agricult 4:11-22

Nair R, Varghese SH, Nair BG, Maekawa T, Yoshida Y, Kumar DS (2010) Nanoparticulate material delivery to plants. Plant Sci 179(3):154-163

Najafi-Ghiri M (2014) Effects of zeolite and vermicompost applications on potassium release from calcareous soils. Soil Water Res 9:31-37

Nazaralian S, Majd A, Irian S, Najafi F, Ghahremaninejad F, Landberg T, Greger M (2017) Comparison of silicon nanoparticles and silicate treatments in fenugreek. Plant Physiol Biochem $115: 25-33$

O'Farrell N, Houlton A, Horrocks BR (2006) Silicon nanoparticles: applications in cell biology and medicine. Int J Nanomed 1(4):451-472

Parisi C, Vigani M, Rodríguez-Cerezo E (2015) Agricultural nanotechnologies: what are the current possibilities? Nano Today 10(2):124-127

Pérez-De-Luque A, Rubiales D (2009) Nanotechnology for parasitic plant control. Pest Manag Sci 65.5:540-545

Rai M, Ingle A (2012) Role of nanotechnology in agriculture with special reference to management of insect pests. Appl Microbiol Biotechnol 94(2):287-293

Rao GB, Susmitha P (2017) Silicon uptake, transportation and accumulation in Rice. J Pharmacogn Phytochem 6(6):290-293

Rastogi SK, Pal P, Aston DE, Bitterwolf TE, Branen AL (2011) 8-Aminoquinoline functionalized silica nanoparticles: a fluorescent nanosensor for detection of divalent zinc in aqueous and in yeast cell suspension. ACS Appl Mater Interfaces 3(5):1731-1739

Rastogi A, Zivcak M, Sytar O, Kalaji HM, He X, Mbarki S, Brestic M (2017) Impact of metal and metal oxide nanoparticles on plant: a critical review. Front Chem 5:78

Roduner E (2006) Size matters: why nanomaterials are different. Chem Soc Rev 35(7):583-592

Roohizadeh G, Majd A, Arbabian S (2015) The effect of sodium silicate and silica nanoparticles on seed germination and growth in the Vicia faba L. Trop Plant Res 2(2):85-89

Rouhani M, Samih MA, Kalamtari S (2012) Insecticidal effect of silica and silver nanoparticles on the cowpea seed beetle, Callosobruchus maculatus F. (Col.: Bruchidae). J Entomol Res 4:297-305

Sabaghnia N, Janmohammadi M (2015) Effect of nano-silicon particles application on salinity tolerance in early growth of some lentil genotypes. Ann UMCS Biol 69:39-55

Sekhon BS (2014) Nanotechnology in agri-food production: an overview. Nanotechnol Sci Appl 7:31

Siddiqui MH, Al-Whaibi MH (2014) Role of nano-SiO 2 in germination of tomato (Lycopersicum esculentum seeds Mill.). Saudi J Biol Sci 21(1):13-17

Slomberg DL, Schoenfisch MH (2012) Silica nanoparticle phytotoxicity to Arabidopsis thaliana. Environ Sci Technol 46(18):10247-10254

Strout G, Russell SD, Pulsifer DP, Erten S, Lakhtakia A, Lee DW (2013) Silica nanoparticles aid in structural leaf coloration in the Malaysian tropical rainforest understorey herb Mapania caudata. Ann Bot 112(6):1141-1148

Sun D, Hussain HI, Yi Z, Rookes JE, Kong L, Cahill DM (2016) Mesoporous silica nanoparticles enhance seedling growth and photosynthesis in wheat and lupin. Chemosphere 152:81-91 
Suriyaprabha R, Karunakaran G, Yuvakkumar R, Prabu P, Rajendran V, Kannan N (2013) Application of silica nanoparticles for increased silica availability in maize. AIP Conf Proc 1512:424-425

Suriyaprabha R, Karunakaran G, Yuvakkumar R, Rajendran V, Kannan N (2014) Foliar application of silica nanoparticles on the phytochemical responses of maize (Zea mays L.) and its toxicological behavior. Synth React Inorg M 44(8):1128-1131

Szerment J, Ambrozewich-Nita A, Kedziora K, Piasek J (2014) Use of zeolite in agriculture and environmental protection. A short review. UDC 666.96:691.5

Torney F, Trewyn BG, Lin VSY, Wang K (2007) Mesoporous silica nanoparticles deliver DNA and chemicals into plants. Nat Nanotechnol 2(5):295-300

Tripathi DK, Singh VP, Kumar D, Chauhan DK (2012) Impact of exogenous silicon addition on chromium uptake, growth, mineral elements, oxidative stress, antioxidant capacity, and leaf and root structures in rice seedlings exposed to hexavalent chromium. Acta Physiol Plant 34(1):279-289

Tripathi DK, Singh VP, Prasad SM, Chauhan DK, Dubey NK (2015) Silicon nanoparticles (SiNp) alleviate chromium (VI) phytotoxicity in Pisum sativum (L.) seedlings. Plant Physiol Biochem 96:189-198
Tripathi DK, Singh S, Singh VP, Prasad SM, Dubey NK, Chauhan DK (2017) Silicon nanoparticles more effectively alleviated UV-B stress than silicon in wheat (Triticum aestivum) seedlings. Plant Physiol Biochem 110:70-81

Tsuji K (2001) Microencapsulation of pesticides and their improved handling safety. J Microencapsul 18:137-147

Ulrichs C, Mewis I, Goswami A (2005) Crop diversification aiming nutritional security in West Bengal: biotechnology of stinging capsules in nature's water-blooms. Ann Tech Issue of State Agri Technologists Service Assoc, Ann Arbor, pp 1-18

Wanyika H, Gatebe E, Kioni P, Tang Z, Gao Y (2012) Mesoporous silica nanoparticles carrier for urea: potential applications in agrochemical delivery systems. J Nanosci Nanotechnol 12(3):2221-2228

Xia T, Kovochich M, Liong M, Meng H, Kabehie S, George S, Zink JI, Nel AE (2009) Polyethyleneimine coating enhances the cellular uptake of mesoporous silica nanoparticles and allows safe delivery of siRNA and DNA constructs. ACS Nano 3(10):3273-3286

Ziaee M, Ganji Z (2016) Insecticidal efficacy of silica nanoparticles against Rhyzopertha dominica $\mathrm{F}$. and Tribolium confusum Jacquelin du Val. J Plant Protect Res 56:250-256 